\title{
Entre Cabanas e Diligências: Os Fronteiriços na Western Fiction de Bret Harte e Ernest Haycox
}

Cesar Augusto Barcellos Guazzelli* Renata Dal Sasso Freitas**

Resumo: Este artigo evidencia como a fronteira americana em seu avanço inexorável para Oeste produziu obras ficcionais muito carregadas de emoção, mesmo passados os tempos épicos dos pioneiros. Mais que isso, elas recriaram os seus dramas fora daquelas paisagens ocupadas pelos grandes rebanhos de gado e seus cowboys, mas justamente nos núcleos civilizatórios que já se haviam instalado no Oeste. A mitologia dos pioneiros mudava para uma realidade menos glamourizada, mas talvez mais verossímil. Assim, o que propomos é uma leitura comparada de dois contos que se reportam ao avanço da fronteira "civilizatória" para o Oeste: The Outcasts of Poker Flat, de Bret Harte, escrita em 1868, e Stage to Lordsburg, de Ernest Haycox, escrita em 1939.

Palavras-chave: Oeste. Pioneiros. Fronteiras. Fronteiriços. Literatura.

* Professor Titular do Departamento de História e do Programa de Pós-Graduação em História da Universidade Federal do Rio Grande do Sul (UFRGS). Contato:cguazza@terra.com.br.

** Bolsista de Pós-Doutorado FAPERGS/CAPES - PPG em História da UFRGS. Contato: renatadsf@gmail.com. 
"Space: the final frontier. These are the voyages of the starship Enterprise." (Gene Roddenberry - Star Trek)

\section{Introdução: \\ Buscando a última fronteira: os espaços e os textos}

A série televisiva Star Trek - "Jornada nas Estrelas" no Brasil foi uma criação de Gene Roddenberg, indo ao ar pela primeira vez em 1966. Ambientada no século XXIII, ela narra as aventuras da nave USS Enterprise, da Federação Unida dos Planetas, na exploração do universo desconhecido. Mais que isso, aparecem os microcosmos dos espaços restritos onde diferentes indivíduos neles confinados precisam ajustar seus comportamentos e desejos em função de algo maior; muitas vezes a própria sobrevivência está em plano secundário em relação à do grupo.

Mas se a "dobra espacial" permite que a Enterprise use uma velocidade maior que a luz para difundir por toda galáxia uma mensagem de paz que já foi alcançada na Terra; outras visões da conquista sideral apresentam as mesmas ideias que estão presentes nos Estados Unidos desde os tempos da expansão territorial a partir de fins do século XVIII. Um texto de Guazzelli procurou identificar na película Independence Day ${ }^{1}$ elementos análogos aos westerns tão caros ao cinema norte-americano: o presidente/xerife que enfrenta os alienígenas/indígenas, apoiado por outsiders distantes do tipo $\mathrm{WASP}^{2}$ mais desejável; um judeu, um negro e um alcoólatra salvam o planeta onde as Forças Armadas/cavalaria fracassaram. (GUAZZELLI; BECK, 2010).

No mesmo tom, a respeito de Star Wars - "Guerra nas Estrelas", no Brasil - escreveu John Jakes: "To my mind, Star Wars is a conventional Saturday afternoon cowboy vs. bad men picture decked out with stunning visuals"4. Segue ele a respeito das lutas pelo domínio da galáxia entre um maléfico Império contra forças democráticas, travadas por naves que, através do "hiperespaço", superam a velocidade da luz: "The Western just changed clothes. Horse opera became sapace opera" ". (JAKES, 2000, p. 12).

Anos 90, Porto Alegre, v. 22, n. 41, p. 209-236, jul. 2015 
Assim, pensar em Western - seja a literatura ou o cinema implica conceber a "fronteira final" como um mito fundacional dos Estados Unidos que se projeta para outros espaços fora do país e em outros tempos. Já sua associação com grupos humanos isolados e entregues aos seus próprios destinos foi divulgada desde as primeiras letras impressas da recém-fundada nação. $\mathrm{O}$ americano, rude, obstinado e destemido fazia sozinho a fronteira, num peculiar intercâmbio ideológico entre o fatalismo divino do Destino Manifesto e a livre iniciativa de um capitalismo que nascia muito predador. $\mathrm{O}$ avanço deste novo homem era feito engolindo terras, indígenas, estrangeiros, até que o oceano do oeste não desse mais vau... Somente muito depois as naves americanas - de negócios ou de guerra - tratariam de tragar também as fronteiras marítimas e além!

Os primeiros escritos sobre os homens da fronteira nos EUA apareceram logo após a independência, e eram relatos de pioneiros que se internavam na Louisiana ${ }^{6}$, ou de cativas resgatadas dos indígenas. O de maior impacto antes do século XIX foi a "memória" de Daniel Boone, que havia vivido e lutado contra os índios, que participara da Revolução de Independência e que descobrira vários caminhos para o mítico Oeste: além do Kentucky, como batedor primeiro e pioneiro depois, ele teria ido muito além do Mississipi e chegado a Yellowstone. O relato de Boone, escrito por John Filson em 1794, foi best-seller nas cidades do Leste e na Europa (BOONE, 1996). Os riffemen - referência aos seus longos fuzis Kentucky - da fronteira, eram resultado da mistura entre brancos e índios, ao menos cultural, visto com ambiguidade: não era possível conviver com eles, mas eram necessários para proteger as fronteiras. (GUAZZELLI, 2003)

Por conta não apenas disso, mas também de uma tradição vinculada às primeiras manifestações do que se pode chamar de romantismo europeu, mais precisamente através dos escritos de René-François de Chateaubriand, a vida na fronteira ofereceu-se como uma temática conspícua para os letrados norte-americanos que desejavam escrever romances sobre a nação recém-independente. Um deles era Charles Brockden Brown (1771-1810), com seu Edgar Huntly; or Memoirs of a Sleep-Walker, de 1799, ambientado no interior da Pennsylvania, cujo enredo envolve encontros do protagonista com indígenas da tribo dos Delaware (BROWN, 1799). Ainda na década de 1820, a questão

Anos 90, Porto Alegre, v. 22, n. 41, p. 209-236, jul. 2015 
do que caracterizaria uma literatura nacional ainda perturbava a incipiente cena literária do país, ao ponto de James Fenimore Cooper, mais tarde estabelecido no cânone como detendo a paternidade do romance nos Estados Unidos, começar sua carreira emulando os romances da inglesa Jane Austen, com Precaution (1820).

Em 1823, no entanto, Cooper publicou o primeiro romance da série que se tornaria conhecida como The Leatherstocking Tales ${ }^{7}$, The pioneers (COOPER, 1964) propunha-se como uma narrativa descritiva na vida da fronteira do estado de New York, em 1793, tratando de uma ficcionalização da vivência do pai do romancista na cidade que este fundou após o término da Guerra de Independência, Cooperstown, no livro chamada de Templeton ${ }^{8}$. Depois de ainda escrever mais dois romances sobre a Guerra de Independência, foco dos esforços de diversos autores nesta década em escrever sobre temáticas americanas, Cooper publica em 1826 sua obra mais famosa: The Last of the Mobicans (COOPER, 1989), que estabelece como protagonista um dos personagens de The Pioneers, o caçador Natty Bumppoo, chamado no primeiro romance de Leatherstocking e nesse segundo de Hawkeye, juntamente com o indígena em The Pioneers, chamado John Mohegan, mas rebatizado de Chingackook, a Grande Serpente. Bumppo é o centro de três outros romances: The Prairie (COOPER, 1987), de 1827, quando Cooper deu a série por encerrada pela primeira vez, e nos tardios The Pathfinder (COOPER, 1980), de I840, e The Deerslayer (COOPER, 1982), de 1841. Cooper escreveu largamente sobre outras temáticas, incluindo aí romances ambientados na Europa e os romances navais, outro gênero ao qual lhe atribuem proeminência. No entanto, é pela série do Leatherstocking e os múltiplos tropos típicos das narrativas western, é pela qual ele é mais conhecido.

É importante afirmar que Cooper se increve em uma tradição de escrita de prosa de ficção que deve muito às obras de Sir Walter Scott, principalmente os romances Waverley ${ }^{9}$, que ainda estavam sendo publicados anonimamente quando Cooper iniciou sua carreira de romancista. Deles, Cooper retira algumas convenções narrativas e estruturais, entre elas principalmente o herói ambíguo, que circula entre dois mundos em conflito - no caso de Natty Bumppo, entre brancos e indígenas - sem filiar-se a nenhum dos dois. Para escrever 
suas obras, assim como o escocês, Cooper inicialmente valia-se de sua experiência vivendo nos cenários sobre os quais escrevendo, e de uma extensa pesquisa documental, ao qual, em comparação a Scott - um notório antiquário - ele fazia pouca referência em notas. As fontes de seus romances e os topos que informam seus romances de fronteira mais específicas em relação à realidade norte-americana são as narrativas de fronteiras aqui mencionadas, tais como relatos de cativeiro, relatos de caçadores fronteiriços e relatos de missionários, que circulavam pelo território norte-americano desde o século XVIII, trazendo as experiências daqueles que haviam se disposto a enfrentar o inóspito território desconhecido. Tais narrativas não cessam de aparecer com a popularização dos romances de Cooper e de outros autores contemporâneos a ele.

No entanto, ainda 1834, um outro pioneiro repetiria Boone: Davy Crockett, nascido na fronteira do Tenessee, caçador que também combateu indígenas, depois de uma carreira política exitosa como deputado, publicou suas memórias (CROCKETT, 1987). Sua morte trágica lutando pela independência do Texas contra os mexicanos em 1836, faria um elo entre o caçador das florestas e o cowboy de um novo Oeste, deslocando o modelo do "homem americano", ainda e sempre um fronteiriço. ${ }^{10}$ Muitas histórias lendárias sobre Crockett sobreviveriam nas dime novels profusamente difundidas no século XIX. ${ }^{11}$

A popularização do vaqueiro das gadarias texanas e de outras partes do Oeste, apesar de muito grande, foi tardia na produção literária norte-americana; possivelmente por colocar-se já como um "herdeiro" de combates anteriores pela construção da nação, o cowboy, seja uma figura pouco dramática para a literatura do século XIX. Com certo açodamento, o ainda jovem escritor argentino Jorge Luis Borges afirmava, num ensaio de 1932, que o cowboy dos Estados Unidos "[...] pesa menos en la literatura de su país que que los chacareiros del Middle West o que los hombres negros del Sur." (BORGES, 2012, p. 13-14). Contrariando esta opinião, Hobsbawm, num ensaio sobre o mito dos cowboys, pergunta por que "[...] um grupo social e economicamente marginalizado de proletários desarraigados, que surgiu e desapareceu no decurso de duas décadas nos Estados Unidos do século XIX, teve uma sorte global tão extraordinária, e a rigor tão unica?’" (HOBSBAWM, 2013 , p. 310, grifos nossos)

Anos 90, Porto Alegre, v. 22, n. 41, p. 209-236, jul. 2015 
Parece mais aceitável a impressão de Hobwsbawm, se pensarmos que ao menos três Presidentes dos Estados Unidos buscavam se identificar como cowboys! $!^{12}$ Exageros de um e outro lados a parte, a literatura norte-americana aponta para outros tipos humanos do Oeste que inspiraram as mais apreciadas obras do gênero Western Fiction, como ficariam conhecidas. Nesse sentido, aquela dramaticidade reclamada pela literatura estaria, como escreveu Hobsbawm: "A imagem original do Faroeste, suponho, contém dois elementos: o confronto entre natureza e civilização, e o confronto entre liberdade e restrições sociais". (HOBSBAWM, 2013, p. 316, grifos nossos) Ou seja, o autor recupera aqui a mensagem de Cooper, como explicita no mesmo ensaio: "Os verdadeiros heróis do Oeste eram indios, e caçadores que aprenderam a viver com e como indios - a rigor, Leatherstocking e Chingachgook". (HOBSBAWM, 2013, p. 317, grifos nossos)

E nesse sentido que este artigo se insere. Buscaremos aqui evidenciar como a fronteira em seu avanço inexorável para Oeste seguiu produzindo obras ficcionais ainda muito carregadas de emoção, mesmo passados os tempos épicos dos pioneiros. Mais que isso, elas recriaram os seus dramas fora daquelas paisagens ocupadas pelos grandes rebanhos e seus cowboys, mas justamente nos núcleos civilizatórios que já se haviam instalado no Oeste. Saía de cena a mitologia e entrava uma realidade menos glamourizada e talvez mais verossímil. Assim, o que proponho é uma leitura comparada de dois contos que se reportam ao avanço da fronteira "civilizatória" para o Oeste: The Outcasts of Poker Flat, de Bret Harte, escrita em 1868 (HARTE, 2001) ${ }^{13}$ e Stage to Lordsburg, de Ernest Haycox, escrita em 1939.

O primeiro deles é ambientado na Califórnia, em 1850; o segundo, no Arizona, em 1880. No primeiro, as cidades emergentes tratam de expulsar seus indesejáveis para lugares inóspitos; no segundo, cidadãos e indesejáveis unem-se contra os apaches rebelados sob comando de Gerônimo. O primeiro, junto a outros contos e narrativas do autor, trouxeram a Harte grande prestígio e popularidade; motivou uma película, que está perdida. ${ }^{14} \mathrm{O}$ segundo, de um autor muito prolífico, deu-lhe mais combustível para sua prolificidade e resultou num filme épico dos mais reverenciados. ${ }^{15}$ No primeiro, rudeza e brutalidade; no segundo, também muita rudeza e brutalidade. Em ambos, dignidade e beleza por detrás disso tudo. 
Há uma distância óbvia entre os gêneros, na medida em que o conto permite uma linguagem mais seca, linear e objetiva, que está conforme aquela atmosfera desejada pelos autores. Mesmo assim, penso existir aqui uma diferença significativa em relação aos relatos de pioneiros e os tomances históricos de Copper indicados no início. Em relação aos primeiros, escritos, na verdade, por ghost-writers da imprensa, os protagonistas dedicam-se meticulosamente a contar suas biografias salientando as próprias importâncias para o avanço dos domínios da nação, apesar das agruras da natureza e do enfrentamento com os indígenas hostis. Já ao pai da literatura dos Estados Unidos, segue os principais protocolos da pesquisa documental de então, com detalhadas descrições de paisagens, atribuindo a si mesmo o conhecimento dos ambientes de suas narrativas, idealizando e estereotipando seus personagens, identificado com o romantismo de seu tempo.

Mas talvez o mais interessante nos contos de Harte e Haycox seja a solidão que paira por trás da secura e do silêncio, das frases duras e dos gestos sóbrios. O homem e a mulher da fronteira contam-se aos dedos, e estão longe de qualquer socorro; os proscritos numa perdida cabana de troncos que mal aguenta o rugir do blizzard e os viajantes na diligência solitária no deserto do Arizona, fustigados pelos bravos seguidores de Gerônimo. Nesses silêncios longos intercalados por diálogos curtos vão-se desvelando em poucos traços personagens bem definidas, numa escrita que se tornou característica da literatura norte-americana.

\section{A vida é jogo: sorte e azar na cabana!}

Iniciando por Harte, são apropriadas algumas considerações mais gerais sobre sua produção. Bret Harte é um dos criadores de uma escrita ficcional que se tornaria canônica na literatura norte-americana. Alguns estudiosos atribuem ao autor toques de leveza e poesia; Carolina Nabuco afirma categoriamente: "Foi um contista pitoresco e romântico, sem realismo e frequentemente sem realidade. O que ele servia aos leitores era o que eles desejavam quer fosse de fato aquela região cheia de riquezas para desenterrar". (NABUCO, 2000, p. 146, grifos nossos).

Anos 90, Porto Alegre, v. 22, n. 41, p. 209-236, jul. 2015 
Predominam, no entanto, aqueles que percebem no autor a prevalência de personagens fortes e duros, como os que ele conviveu com mineiros nas suas andanças californianas durante a famosa Corrida do Ouro. Margolin, por exemplo, afirma sobre personagens de sua obra: "Preachers tote six shooters as they face off with highwaymen, horse thieves, and self-sacrificing prostitutes" ${ }^{\prime 6}$. (MARGOLIN, 1997, p. X). Mempo Giardinelli escreve que Harte e outros contemporâneos - cita Ambrose Bierce, Stephen Crane, Zane Grey e Mark Twain - "[...] influyeron directamente a los escritores que invetaron décadas después la literatura policial negra.” A característica fundamental era a construção dos protagonistas de suas histórias: "Todos, sin excepción, elevaron al primer plano la literatura a un nuevo tipo de héroe: el solitario antes que el superhombre, el sujeto muchas veces desdichado y siempre crítico de las conquistas". (GIARDINELLI, 2013, p. 33). Gary Scharnhosrst também ressalta o papel inovador de Harte: "He was a literary pioneer who helped develop a formula, including an ensemble of characters, to which western writers have subscrived ever since"17. (SCHARNHORST, 2001, p. xxiv).

Por trás de diversas narrativas suas estão suas vivências na Califórnia, onde chegou em 1854, nos tempos da mineração de ouro, onde trabalhou como minerador, mas também como mestre-escola, balconista, funcionário de correios; também pode atuar como tipógrafo e jornalista, o que lhe daria material para suas narrativas. Nesse sentido, tem mais uma parecença com outros autores realistas importantes dos Estados Unidos - como os citaram Twain, Bierce e Crane - cujas vivências no Oeste depois apareceriam nas suas obras. ${ }^{18}$

Suas primeiras publicações de sucesso ocorreram após 1857, e em 1864 foi contemplado com um emprego público que lhe permitiu se dedicar inteiramente à Literatura. Publicou, a partir de 1867, seus principais contos, como The Luck of Roaring Camp, Tennessees Partner, Miggles e muitos mais (HARTE, 2001). Nessas narrativas circulam mineiros, escroques, jogadores, prostitutas, numa gama variada de atividades próprias da Corrida do Ouro e da atração que exerceu durante seu ciclo.

Dentre estes bem recebidos contos de Harte, The Outcasts of Poker Flat pode ser considerado o mais dramático deles. Para começar, 
ele foi inspirado num trágico incidente ocorrido em 1846, quando um grupo de 81 imigrantes que tentavam chegar à Califórnia foram bloqueados pela neve no Donner Pass - um desfiladeiro que era a única travessia para os imigrantes que vinham do Leste - durante todo o inverno, sobrevivendo apenas 45 deles. (SCHARNHORST, 2001, p. XII). Ou seja, para alcançar a "terra da promissão" havia que sobreviver às rudezas de uma paisagem ainda muito agreste, e os aprêmios da fronteira californiana repetiam aqueles de outros espaços ainda por conquistar no Oeste. Mais importante, porém, é a dimensão social que toma conta do início da narrativa, pois também aqui a fronteira mostra-se cruel.

John Oakhurst, o jogador profissional da cidade, em 23 de novembro de 1850 , observou um clima ameaçador por parte da população ${ }^{19}$. Ele sabia de uma comissão secreta que se formara para expulsar da cidade as pessoas indesejáveis, a pretexto de perdas econômicas, furtos e condutas inadequadas. Dois destes indesejáveis haviam sido linchados, vítimas do moralismo que se instalara: "It was experienced a spasm of virtuous reaction, quite as lawless and ungornevable as any of the acts that have provoked it." ${ }^{20}$ (HARTE, 1997 , p. 12) Reunidos a ele no grupo de expatriados estavam uma jovem conhecida como Duchess; uma mulher mais madura, Mother Shipton; e Uncle Billy, o bêbado da cidade e suspeito de ser "sluice-robber", nestes tempos, um crime grave. ${ }^{21}$

É notável que apenas o jogador é apresentado pelo seu próprio nome. Talvez aqui um trocadilho com "oak" - lembrando a imponência dos carvalhos californianos! - do seu sobrenome já prenunciasse a força interior que mostraria nos dias subsequentes à expulsão; parece ser mais óbvio o nome da cidade, associada diretamente ao jogo que era profissão de Oakhurst, mas aponta para uma "aposta" nos rumos da própria Corrida do Ouro. Por outro lado, apesar de não estar explícito, as duas mulheres estão vinculadas à prostituição: a apresentação da jovem como "familiarly known as The Duchess" 22 denota que o apelido jocoso era de uso corriqueiro, portanto, caracterizando-a como quem convive com muitos homens. Por outro lado, Mother Shipton satiriza o papel maternal autoatribuído pelas cafetinas ou donas de prostíbulos. Enfim, a cidade livrava-se de homens que - jogando ou roubando - tomavam-lhe o dinheiro, e 
de putas que corrompiam seus costumes. Levados aos limites de Poker Flat, eles foram jurados de morte caso regressassem à cidade.

Entre uma chorosa Duchess e as imprecações de Mother Shipton e Uncle Billy, Oakhurst mantém a fleuma de jogador e lidera o grupo no rumo de Sandy Bar, uma localidade mais recente que Poker Flat, provavelmente mais receptiva aos exilados. Aqui outro jogo de palavras: saiam de um lugar mais "civilizado" - Poker é um jogo de salão - para um mais "bárbaro" - Sandy, uma paisagem agreste! Mas a viagem é interrompida devido às lamúrias de Duchess, e o grupo faz uma pausa para descansar ao meio-dia. Esta parada crucial - de novo as opções ao azar! - além do atraso na viagem provoca um encontro inesperado com dois outros protagonistas da história: os jovens Tom Simpson - apelidado The Innocent - e sua namorada Piney Woods, de apenas quinze anos, que fugiam no caminho inverso para se casarem em Poker Flat. De novo o autor brinca com os nomes: a referência que o nome da moça faz à "pureza" de uma mata de pinheiros funciona como uma analogia à "inocência" na alcunha do seu companheiro.

Oakhurst lembrava vagamente de Piney, pensando que ela talvez servisse as mesas do saloon, ironicamente chamado de Temperance House. Mas Tom era seu conhecido! Algum tempo antes, ele havia tentado a sorte no jogo contra Oakhurst numa passagem por Poker Flat, perdendo todo seu dinheiro para o profissional. No entanto, chamado pelo jogador que lhe disse: "Tommy, you're a good little man, but you can't gamble worth a cent. Don't try it over again"23. (HARTE, 1997, p. 15) O rapaz sentia-se devedor e tratou de servir ao máximo os viajantes; reprimindo os risos e as chacotas de Billy, o jogador impressionou-se com a inocência do jovem casal, que atribuía aos quatro exilados as mesmas qualidades que tinham. Tom, então, propõe que acampem juntos nesta noite numa velha cabana de troncos próxima de onde estavam; contra as objeções de Oakhurst - que não queria decepcioná-los revelando as causas da saída de Poker Flat - o rapaz ofereceu inclusive as fartas provisões de boca que levava.

Assim decididos, a cabana foi destinada a Piney, Mother Shipton e Duchess, enquanto os homens dormiriam ao relento: "Piney can stay with Mrs. Oakhurst,' said the Innocent, pointing to the Duchess, 'and I can shift for myself."'24 (HARTE, 1997, p. 15-16) Tratar Duchess 
como se fosse a esposa do jogador pressupõe que Tom pensasse que ela fosse uma duquesa de verdade! Criavam-se algumas situações embaraçosas, especialmente para as duas mulheres: "II reckon now you're used to fine things at Poker Flat,' said Piney. The Duchess turned away sharply to conceal something that reddened her cheeks through its professional tint, and Mother Shipton requested Piney not to "chatter"'25. (HARTE, 1997, p. 17). As roupas e objetos espalhafatosos que usavam no saloon de Poker Flat não causava desconfiança na donzela!

Oakhurst despertou de madrugada, vendo que se aproximava uma grande tempestade de neve. Para piorar as coisas, constatou que Uncle Billy fugira com as mulas e seu cavalo, deixando-os a pé; felizmente, as provisões trazidas por Tom estavam acomodadas na cabana e garantiam mais ou menos dez dias de alimentação para o grupo. Como um gambler acostumado à fortuna, não fez alarde com a tragédia que esta situação poderia representar: "He did not waken the sleepers. The Innocent slumbered peacefully, with a smile on his good-humored, freckled face; the virgin Piney slept beside her frailer sisters as sweetly as though attended by celestial guardians" $"$. (HARTE, 1997, p. 17) Mais tarde - com a conivência de Duchess e Mother Shipton - convenceu os jovens de que Billy saíra em busca de mais provisões para todos e que provavelmente estava perdido. Assim ficou o grupo na rude cabana aguardando que a nevasca terminasse.

Durante os dias que transcorreram, Tom e Piney encantaram os três proscritos com seus gestos e palavras, seja quando cantavam hinos religiosos ao som do acordeon de Piney, seja quando The Innocent contava aos demais sua versão própria da Ilíada, que havia lido tempos atrás. $\mathrm{Na}$ segunda noite passada na cabana, num momento de franqueza, Oakhurst contou a Tom qual era a sua "filosofia" de vida: "'Poker!' replied Oakhurst, sententiously; 'when a man gets a streak of luck - nigger luck - he don't get tired. The luck gives in first. Luck,' continued the gambler, reflectively, 'is a mighty queer thing. All you know about it for certain is that it's bound to change" 27 . Calmamente ele explicou que isso dizia respeito às agruras que estavam vivendo: "And it's finding out when it's going to change that makes you. We've had a streak of bad luck since we left Poker 
Flat - you come along, and slap you get into it, too. If you can hold your cards right along you're all right"'28. (HARTE, 1997, p. 18-19)

No décimo dia, MotherShipton chamou Oakhurst para lhe dizer que estava morrendo, e queria que o jogador apanhasse um pacote sob sua cabeça; nele estavam as rações que lhe cabiam durante estes dias, e que ela poupara para Piney: '“Give 'em to the child,' she said, pointing to the sleeping Piney. 'You've starved yourself,' said the gambler. 'That's what they call it,' said the woman, querulously, as she lay down again and, turning her face to the wall, passed quietly away." ${ }^{29}$ (HARTE, 1997, p. 20) Foi um dia de tristeza, sem as já habituais sessões de contar história, cantar ou tocar acordeon.

Com a situação tornando-se já desesperadora, Oakhurts chamou o rapaz de lado e lhe disse que ele tinha uma chance mínima de salvar Piney, desde que fosse para Poker Flat sozinho e lá chegasse em dois dias no máximo. Explicou-lhe também que deveria ficar para acompanhar as duas mulheres que restavam. Nas despedidas, Duchess perguntou ao jogador, que parecia preparado para acompanhar Tom, se ele também se retirava: “'As far as the canyon,' he replied. He turned suddenly, and kissed the Duchess, leaving her pallid face aflame and her trembling limbs rigid with amazement" 30 . (HARTE, 1997, p. 21) Com este inusual gesto de carinho, o jogador não precisava explicar o destino que os esperava.

Três dias ainda se passaram antes de consumado o destino. Elas passaram este tempo abraçadas, quase sem falar, já sem forças para reavivar o fogo ou até para comer as migalhas que ainda restavam. "Piney, you can pray?' 'No dear', said Piney simply". ${ }^{31}$ (HARTE, 1997, p. 21) Esta foi a última troca de palavras entre as duas. Para surpresa da jovem donzela, foi a pecadora que se aninhou no seio dela e dormiu. Quando a expedição salvadora chegou, as duas estavam congeladas neste abraço, e impossível distinguir nesta visão a virtuosa da pecadora. Mais afastado da cabana, os homens da Lei de Poker Flat encontraram o corpo de Oakhurst com um Derringer decarregado na mão e um tiro no peito, ao pé de uma árvore. Nela estava cravado com uma faca um bilhete escrito a lápis: "Beneath this tree lies the body of John Oakhurst, who struck a streak of bad luck on the $23 \mathrm{rd}$ of november, 1850, and handed in his checks on the 7th december, 1850 "32. (HARTE, 1997, p. 22, grifos do autor). 
Este é o conto de Bret Harte. O que ele conta para nós? O autor foi, de alguma maneira, testemunha viva do que era o Ciclo do Ouro da Califórnia, que talvez pudesse ser entendido como o futuro dos Estados Unidos. Jogadores, prostitutas, ladrões de calha, inocentes incapazes de verem o que salta aos olhos, já se tornavam marcas de um passado ainda muito recente. Mas esta realidade daria lugar a uma economia controlada por capitalistas práticos e objetivos, que não se entregariam aos azares da sorte que caíram sobre o gambler tão fatalista. A Califórnia podia - aos tempos de Harte - ser um jogo, com viradas de fortuna e má sorte. A própria vida do autor trazia um pouco disso.

Em todo caso, não era o Oeste alardeado como a terra encantada capaz de satisfazer a todos que o buscavam. Também não era um espaço de liberdade em que cada um geria seu próprio destino. Tampouco aparecem os westernmen tão propagandeados pela imprensa das cidades do Leste. Harte escreve de forma direta, ácida e seca uma realidade brutal; a natureza pode ser indomável, e a vida nos centros urbanos traz suas predicações, leis e interditos. Talvez aquilo que Cooper intuíra em relação ao seu experimentado pioneiro, enxotado dos lugares que agregara ao mundo civilizado (COOPER, 1964), podia agora ser testemunhado pela nova literatura que aparecia com Harte e outros. O Oeste não tinha glamour, era hostil, e nele sobreviviam os que fossem fortes o bastante para dirigirem os rumos dos espaços ocupados. Das cidades, feiras, minas ou fábricas mais tarde; ou até diversão, jogos e mulheres. Não sobraria espaço para os que aventuravam e confiavam nas cartas!

$\mathrm{Na}$ última frase do conto, Harte diz que Oakhurst "[...] was at once the strongest and yet the weakest of the outcasts of Poker Flat"33. (HARTE, 1997, p. 22). Esta seria uma menção ao próprio Oeste que era desbravado. Os tempos "heróicos" dos pioneros chegava ao fim, e os valentes tornavam-se fracos frente às mudanças que rapidamente incorporariam a Califórnia aos projetos nacionais - e internacionais! - mais importantes para os Estados Unidos.

Uma última parábola, quem sabe! Na chegada fracassada do socorro vindo de Poker Flat, reuniam-se duas - por assim dizer! gerações formadoras dos Estados Unidos. Na cabana, morrera a "inocência" do Velho Oeste, das florestas virgens como Piney Woods; 
também morreram os donos da "aventura" da conquista, do saloon dos jogadores, das mulheres; ficaram vencedores a "lei e a ordem" que enterraram os mortos na neve. A neve, banho lustral para iniciar a era do progresso e da riqueza. Em breve, no lugar do tétrico Donner Pass, a Califórnia seria alcançada por modernas ferrovias.

\section{A vida é viagem: poeira, areia e pedras no caminho!}

Harte e outros já citados autores do século XIX foram fonte de inspiração para uma grande quantidade de escritores que se valeram do "Velho Oeste" como cenário para muitos romances, contos e até outras formas de narrativa. Afirma Margolin: "From Harte's stories sprouted countless legends and tall tales, eventually the stuff of Westerns and TV serials" 34. (MARGOLIN, 1997, p. XI). Entre tantas produções, merecem lembrança uma grande quantidade de edições populares herdeiras das dime novels, no formato de pequenos volumes impressos em papel de baixa qualidade. (JAKES, 2000, p, 20). Escrevendo sobre os "romances negros" da literatura policial, Guardinelli viu nestes livros outro vínculo com as publicações sobre o Oeste: "El vehículo original, y principal, de ambos fueron las pulp magazines, que así de llamaba a las revistas de relatos de acción, las que debian su nombre al hecho de estar impresas en un ordinario papel de pulpa”. (GIARDINELLI, 2013, p. 44).

Mas além das incontáveis pulps, o tema do Oeste foi marcante na obra de muitos autores que se tornaram paradigmáticos, vários dos quais inspiradores de alguns dos mais importantes cineastas norte-americanos. Ainda é Guardinelli quem escreve que, baseados em “[...] un estilo literario seco, duro, ácido", criado no século XIX, cresceram "[...] varios escritores, entre ellos Ernest Haycox, Albert Pike, Manlove Rhodes y MacLeod”. (GIARDINELLI, 2013, p. 38). Um exemplo mais recente desta literatura seria Elmore Leonard, um escritor já canônico que iniciou uma significativa novelística a partir dos anos cinquenta do século passado (JAKES, 2000, p. 15).

Ernest Haycox foi um dos muitos que publicaram pulp fictions no início dos anos vinte. Mas, já no fim desta década, ele iniciaria uma significativa produção literária, que contaria com 25 romances 
e mais de trezentos contos! É importante destacar que foi marcante no início de sua carreira a escrita de contos e romances no gênero "histórico", focalizados também na Revolução Americana; isto garantiu a suas obras uma verossimilhança que era rara na literatura deste gênero. Sua colaboração em jornais e revistas de renome foi fundamental para a difusão da sua obra, bem como a inspiração que alguns de seus escritos deram para o cinema Western, como foi o caso do conto que analisamos.

Assim como Harte e outros, ele também teve uma vivência no Oeste, na fronteira californiana com o México em 1914, na expectativa de combater uma invasão do território pelo revolucionário mexicano Pancho Villa; na época, com apenas quinze anos, servia na Guarda Nacional do Oregon, com idade falsificada nos documentos. Nesta mesma condição, foi soldado na Primeira Grande Guerra. Essas vivências foram inspiradoras das primeiras publicações jornalísticas de Haycox, onde desenvolveu um estilo mais aproximado dos grandes escritores policiais da época, tais como Hammet e Chandler; são típicos os diálogos muito curtos, que se intercalam quase sem pausas aos fatos que se sucedem nas narrativas (GIARDINELLI, 2013, p. 36-44).

O enredo de Stage $e^{35}$ to Lordsburg é muito direto, quase linear. Depois de 45 dias sem comunicações, a viagem de diligência iniciava em Tonto, no Arizona, com destino à localidade de Lordsburg, Novo México. Na primeira frase, é dada a referência temporal da história: "This is one of those years in the Territory when Apache smoke signals spiraled up from the stony mountain summits"36 (HAYCOX, 2000 , p. 413). Esmiuça mais adiante o alto risco desta travessia: "Out below in the desert's distance stood the relay stations they hoped to reach and pass. Between lay a country swept empty by the quick raids of Geronimo's men" ${ }^{37}$ (HAYCOX, 2000, p. 414); ou seja, entre 1877 e $1886 .{ }^{38}$ Esperava-se que estivessem intactas as estações para descanso, alimentação e trocas de animais que existiam ao longo do caminho no deserto.

A diligência - puxada por seis cavalos - está a postos na praça de Tonto, conduzida por Happy Stuart, acompanhado na boleia pelo guarda John Strang; ao lado do veículo, há uma escolta de dez soldados de cavalaria. Distribuem-se os lugares: no primeiro assento, 
de costas para o caminho, estão: um jogador, um inglês e um moço loiro; no banco de trás, ficavam duas mulheres, uma delas viajando para casar-se com um oficial do exército, a quem o autor se refere sempre como "army girl"; nos assentos intermediários, um vendedor de uísque e um criador de gado. Todos são estranhos uns aos outros, mas o cocheiro e seu guarda repararam com cuidado no homem loiro. Os personagens são inominados e descritos em rápidos traços: o inglês ossudo, com um fuzil de caça, o pecuarista como homem de ombros largos; do comerciante de uísque, a única informação é sua procedência de Sains Louis, e, do jogador, nada se conta.

A outra mulher, também jovem, chegou na hora da partida, e é a única que merece uma descrição mais atenta: "[...] a girl known commonly throughout the Territory as Henriette came quietly from the crowd. She was small and quiet, with a touch of paleness in her cheeks and her quite dark eyes lifted at the blond man's unexpected courtesy, showing surprise" 39 . Enquanto embarca, os homens que assistem à saída da diligência riem ironicamente dela, mas calam-se ao olhar ameaçador do homem loiro:

Men in the crowd were smiling but the blond one turned, his motion like the swift cut of a knife, and his attention covered that group until the smiling quit. He was tall, hollow-flanked, and definitely stamped by the guns slung low on his hips ${ }^{40}$. (HAYCOX, 2000, p. 413-414).

Distinguem-se entre os passageiros uma mulher que causa desprezo e um homem que provoca temor; indesejáveis entre gente de bem?

Sobre a jovem, o autor mostra apenas indícios - que logo no início da viagem se confirmam! - de que a posição social dela que não está à altura dos demais, e que possivelmente seja uma prostituta: o nome francês Henriette ${ }^{41}$ soa como alcunha "profissional", enquanto a expressão "comumente conhecida no território" 42 insinua uma grande quantidade de "relações", muito mais que amizades ou parentescos. Salienta igualmente a surpresa dela em observar cortesia no jovem loiro, por ser totalmente contrário aos deboches dos que ficam. Em nenhum momento, entretanto, isto se torna explicito. No final do dia, na parada da diligência para descanso noturno, num 
curto diálogo com o loiro, responde quando é perguntada se tem parentes em Lordsburg: "She spoke in a direct, patient way as though explaining something he should have known without asking. 'I run a house in Lordsburg""43 (HAYCOX, 2000, p. 420) "Uma casa" assim tão indefinida significa veladamente um bordel!

Já o homem loiro, que mais tarde revela se chamar Malpais Bill, é apresentado como calado, quase taciturno, capaz de impor-se sem palavras ou grandes gestos, mas visivelmente temido pelos que o conhecem. Desde o olhar trocado entre Stuart e Sprang, passando pelo domínio sobre a multidão que ria de Henriette, a breve descrição de que porta dois revólveres com coldres baixos, indica que ele é acostumado ao uso das armas, senão um pistoleiro propriamente dito. Por outro lado, o nome Malpais é derivado da palavra espanhola malpaís - que no Arizona substitui o inglês badland - que se refere a terrenos duros, inviáveis para plantar e para abrir caminhos, derivados de rochas vulcânicas esfareladas. Além de apontar para o próprio território da viagem, revela a profunda identidade desse homem com a brutalidade do meio. Aparece num diálogo entre $\mathrm{o}$ condutor e o guarda a suspeita de que Malpais tem algum objetivo oculto nessa viagem: "Johnny Strang shifted the gun in his lap. 'What's Malpais Bill ridin' with us for?' 'I guess I wouldn't ask him,' returned Happy Stuart” 44 (HAYCOX, 2000, p. 416)

Quase todos os passageiros - exceto pelo inglês, que em toda viagem não se faz notar! - mostram-se hostis à presença de Henriette. O mais agressivo é o criador de gado: procura encostar-se nela e exibe a todos seu riso debochado: "[...] cattleman's smile and the boldness of his glance were something as audible as speech"45 (HAYCOX, 2000, p. 414); também o vendedor de uísque apresenta um olhar cínico, ao passo que a noiva do oficial está ruborizada pela presença da moça de vida suspeita ao seu lado. Justo no momento em que a diligência dá uma rápida parada para que a escolta se despeça de Stuart, o jogador, que ainda não fizera nada ofensivo, dirige-se à "army girl" oferecendo seu lugar, para livrá-la da companhia desagradável: "The gambler spoke to the army girl, gently: 'Perhaps you would find my seat more comfortable.' The army girl said 'Thank you,' and changed over." "H6 (HAYCOX, 2000, p. 415) Mesmo jovem, Henriette tem suficiente experiência para reconhecer o distanciamento que 
viam nela o pecuarista, o jogador, o vendedor de uísque e a "army girl'; aqui, apenas Mailpais lhe é simpático, apesar da sua aparência quase selvagem: "Yet something flowed out of him toward her that was different than the predatory curiosity of other men; something unobtrusively gallant, unexpectedly gentle" 47 . (HAYCOX, 2000, p. 415)

As asperezas do caminho provocam um acidente antes da primeira parada; a diligência cai sobre um dos lados, e os homens levantam-na em seguida, menos o vendedor de uísque, que age estranhamente, parecendo sofrer de alguma moléstia. Logo chegam à primeira estação, para uma parada de dez minutos apenas. As informações sobre os apaches são desencontradas: eles poderão ser encontrados ainda no dia seguinte, podem ter atacado um rancho isolado, e há um pelotão de cavalaria nas proximidades da estação, que andam erraticamente. A noiva do oficial está preocupada com a situação e quer saber se encontrarão soldados na parada seguinte, Gap Creek, onde deverão pernoitar. Malpais tem esperança de que a partir dalí possam ser escoltados até o dinal da viagem.

Às quatro da tarde, o vendedor de uísque sofre um desmaio, e a diligência é obrigada a parar. Os homens carregam-no para o ar livre, mas ninguém se preocupa em atendê-lo, exceto Henriette. Ela abraça o doente, sorri calidamente, o consola e só então recebe um olhar de gratidão e suavidade. Esta reação não a surpreende: "There was this wisdom in her, this knowledge of the fears that men concealed behind their manners, the deep hungers that rode them so savagely, and the loneliness that drove them to women of her kind."48 (HAYCOX, 2000, p. 417) De volta à diligência, Henriette segue amparando o vendedor, repetindo-lhe que ficará tudo bem. Pela primeira vez, recebe olhares solidários dos demais, inclusive do arredio e indiferente inglês; no entanto, quando o jogador oferece ajuda, ela apenas responde que o homem já havia morrido em seus braços.

Finalmente chegam a Grap Creek. O encarregado da estação informa que os soldados se dirigiram às montanhas atrás dos indígenas rebeldes, e trata de acomodar as mulheres na casa, enquanto providencia o celeiro para os homens. Mostra curiosidade pela presença de Malpais: "Hello, Bill. What brings you this way?"49 A resposta veio rápida: "Just the trip.” (HAYCOX, 2000, p. 418) Mais tarde, o atendente do balcão cochicha para Malpais: "Better not 
ride to Lordsburg. Plummer and Shanley are there." ${ }^{50}$ (HAYCOX, 2000, p. 419) Pela primeira vez, o autor revela que a viagem de Bill se deve a algum acerto de contas, mesmo sem esclarecer quem são os homens que estão em Lordsburg e podem ameaça-lo.

$\mathrm{Na}$ estação, a noiva do oficial encontra um desalinhado soldado - pela primeira vez, é chamada pelo nome, Miss Robertson - que tem informes sobre seu noivo, o tenente Hauser: ele tinha sido ferido com certa gravidade pelos apaches na véspera, e encontra-se em tratamento em Lordsburg. Apesar de aparentar serenidade na hora em que recebeu as más notícias, durante a noite que se seguiu, ela precisaria das atenções de Henriette, e aqui terminam as últimas resistências a ela.

Antes de se retirarem para dormir, Henriette e Malpais entretêm o primeiro diálogo desde o início da viagem. O passado de ambos ensejando muita incerteza futura. Respondendo sobre sua origem, ela fala sobre um massacre da família quando pequena: "My folk are dead - I think." ${ }^{51}$ Ele refletia que a rudeza desta terra que não poupava os fracos, mas Henriette resistira: "She had survived and had paid for her survival, and looked at him now in a silent way that offered no explanations or apologies for whatever had been"52. (HAYCOX, 2000, p. 420). Assim, ela era digna de uma nova vida, que Malpais poderia oferecer no pequeno rancho ${ }^{53}$ que possuía no Rio Tonto, com uma casa ainda não terminada. No entanto, estava ali porque tinha "[...] a debt to collect". ${ }^{54} \mathrm{~A}$ esta confirmação de que ele tinha contas a saldar com alguém - e que isto o impedia de levar uma vida normal na qual coubesse uma mulher - levou Henriette a desabafar, duvidando que houvesse arranjo possivel: "Everybody in the Territory knows you. Once you were just a rancher. Then you tried to wipe out a grudge and then there was a bigger one to wipe out - and the debt kept growing and more men are waiting to kill you." ${ }^{55}$ (HAYCOX, 2000, p. 420).

O conto iniciou informando que "todo território" conhecia Henriette, e agora diz o autor que Malpais também! Entre viajantes que se desconhecem, que sequer nomes têm na narrativa, mas que pertencem ao grupo das pessoas de bem, estavam estes dois desajustados - uma prostituta atrás de novo lugar de trabalho e um pistoleiro em busca de vingança - que tinham atração mútua, que se gostavam e poderiam reunir suas vidas. Mas ainda havia muitas distâncias a percorrer até Lordsburg.

Anos 90, Porto Alegre, v. 22, n. 41, p. 209-236, jul. 2015 
A viagem recomeçou na madrugada seguinte, e o responsável pela estação afirmou a Stuart que se chegassem ilesos no rancho de Schrieber estariam a salvo dos apaches. Passavam das dez horas quando chegaram ao local, com a casa totalmente destruída e os cadáveres dos donos desnudos e com marcas de torturas. O caminho foi retomado sob estes maus prenúncios, e os viajantes preperaram-se para um ataque agora mais do que certo. Houve intensa troca de tiros entre os indígenas e os defensores, mas a diligência conseguiu chegar a Lordsburg às cinco horas. Apenas o jogador havia sido morto pelos atacantes.

Resolviam-se os encontros amorosos. A army girl era esperada por um oficial que lhe trazia boas notícias sobre a recuperação do seu noivo, e ela foi conduzida aos prantos para vê-lo, finalmente. Malpais acompanhou Henriette que se dirigia a seu novo destino. Ele então propôs que vivessem juntos: "II have watched you for two days.' He stopped, searching his mind to find the thing he wanted to say. It came out swiftly, 'God made you a woman. The Tonto is a pretty country." 56 No entanto, ela respondeu ironicamente: "No. I am known all through the Territory. But I can remember that you asked me." ${ }^{57}$ (HAYCOX, 2000, p. 424). Malpais afasta-se, e Henriette pensa na conversa que tiveram na noite anterior. Suas divagações são interrompidas por quatro estampidos. Quando ela já pensa que nunca mais o verá, e que sua vida seguirá como foi até então, Malpais surge na esquina, sorrindo em sua direção.

Haycox mostra o Oeste de uma forma tão dura quanto Harte. A terra é muito hostil - e o Arizona sequer tem os atrativos naturais da Califórnia, sejam as riquezas ou as paisagens - e seus habitantes precisam ser duros. Há também uma noção de que se joga uma partida a cada etapa do caminho. Sempre paira no ar a questão: onde estão os apaches de Gerônimo? Entretanto, assim como os personagens de Harte, os viajantes de Haycox cumprem seus destinos sem indagações maiores: o negociante de gado terá negócios em Lordsburg; talvez o vendedor de uísque; ou algum lugar para o jogador exercer seus dons; a noiva atrás do oficial de cavalaria; o inglês, ninguém sabe... Os únicos personagens que têm suas sendas reveladas são os responsáveis pela diligência - cumprindo os deveres de uma árdua profissão - e os "indesejáveis", a prostituta e o pistoleiro. 
Também há aqui o simbolismo de um palco fechado, que apenas se comunica com o exterior nos "stages" ao longo do caminho. Mas não há nestes lugares perguntas sobre o porquê da viagem, ela é simplesmente um fato. Chamam a atenção os personagens mal afamados, crescendo as expectativas em relação a Malpais. A diligência passa também por "stages" temporais: neste Oeste ainda trilhado pelas diligências, sofrendo com as chacinas dos indígenas hostis, defendido precariamente pelas tropas de cavalaria, mostra também a "modernização" nas figuras de comerciantes sérios, de promessas matrimoniais formalizadas. Mas assim como serão subjugados os apaches - enviados para os insalubres pântanos da Flórida - ou condenadas as diligências - as grandes ferrovias integrarão o país - talvez estejam também em vias de extinção aqueles seres típicos da "transição", jogadores, prostitutas e homens de coldres baixos. Talvez seja possível ver uma ironia muito fina do autor: aquele inglês que ficou calado todo o tempo, impassível com seu fuzil de caça, poderia ser um daqueles tantos aventureiros europeus que vinham para a América conhecer o "farvest" em seus estertores.

No entanto, ao contrário de Harte, Haycox não resiste a um final feliz. Malpais matou seus desafetos e pode reconstruir seu rancho no Rio Tonto com Henriette, trazendo uma mensagem de otimismo naquela secura de paisagem e de pessoas. Quem sabe, ele próprio, Haycox, não estivesse em meio a uma transição: ele iniciara nos pulps apelativos, mas terminaria nas garras de Hollywood; por mais fiel que o filme Stagecoach seja ao roteiro do livro, ele inegavelmente trouxe um glamour que faria do gênero western um território também romântico.

\section{Considerações finais}

As duas histórias recuperadas neste texto referem-se a um território que é ambíguo, tanto espacial quanto temporãmente falando. Mais ainda, é ambíguo em relação aos seus homens e suas relações. O Oeste está - com perdão pela redundância! - a oeste de algum lugar: ele foi a Louisiana, as Grandes Planícies além Mississipi, as longínquas terras entre as Montanhas Rochosas e o Pacífico. E foi também o vasto território de origem espanhola incorporado pela 
avidez de espaço dos americanos de fala inglesa. Mas ele foi o Oeste que se chamou "far" - o distante, muito distante no espaço! - ele tornou-se em algum momento impreciso "old" - o velho, muito distante no tempo. Sem marcas mais precisas, era território de fronteiras, que caminhavam na incorporação dos espaços e dos tempos.

$\mathrm{E}$, nestas paragens ambíguas, viviam também pessoas de comportamento também fronteiriço, formando sociedades que reproduziam estas contradições. Pessoas "de bem" assumindo condutas abjetas, "indesejáveis" portando-se com bravura e integridade. Claro, um bom caldo de cultura para a geração e reprodução dos mitos, permitindo a difusão de uma ideologia apologética, que legitimava o Destino Manifesto da promessa bíblica, terreno apropriado para semeadura de um desenvolvimento capitalista sem precedentes.

Se é verdade que coube à História e a seus profissionais desvendar o que era encoberto por um discurso oficialista tradutor de um otimismo fundamental e necessário para a empresa difícil de uma grande potência, também a Literatura foi capaz de apontar para as mazelas individuais e sociais dos norte-americanos. Eles foram Oakhurst e Duchess, ou Malpais e Henriette. Eles viveram tempos duros, viveram como pessoas duras, criaram sociedade duras...

Se iniciamos com Jornada nas Estrelas, também podemos terminar apontando para outra fronteira, igualmente carregada de ambiguidades e contradições, aquela entre a História e a Literatura:

La recomposición del pasado que opera la literatura es casi siempre falazjuzgada en términos de objetividad histórica. La verdad literaria es una y otra la verdad histórica. Pero - aunque esté repleta de mentiras - o, más bien, por ello mismo - la literatura cuenta la bistoria que la bistoria que escriben los historiadores no sabe o no puede contar. (VARGAS LLOSA, 2002, p. 11).

\section{BETWEEN CABINS AND STAGECOACHS: THE FRONTIERSMEN IN THE WESTERN FICTION OF BRET HARTE AND ERNEST HAYCOX}

This article shows how the american frontier in their inexorable advance westward produced fictional works heavily loaded of emotion, even past the epic times of the pioneers. More than that, they recreated their dramas out of those landscapes

Anos 90, Porto Alegre, v. 22, n. 41, p. 209-236, jul. 2015 
occupied by large herds of cattle and their cowboys, but precisely in the civilization centers that had already installed in the West. The mythology of the pioneers changed to a less glamorized reality, but perhaps more believable. So what we propose is a comparative reading of two stories that report to the advancing frontier " civilization " to the West: The Outcasts of Poker Flat, Bret Harte, written in 1868 (HARTE, 2001) and Stage to Lordsburg, of Ernest Haycox, written in 1939. Keywords: West. Frontiers. Frontiersmen. Literature.

\section{Notas}

${ }^{1}$ Independence Day, de 1996, dirigida por Roland Emerich e estrelada por Will Smith e Jeff Goldblum.

${ }^{2}$ WASP é a sigla de White, Anglo-Saxon \& Protestant; este seria o modelo ideal do cidadão dos Estados Unidos, ainda persistente em grande parte da população conservadora.

${ }^{3}$ Star Wars (Guerra nas Estrelas) é composta por seis filmes dirigidos por George Lucas, lançados entre 1977 e 2005, estrelado por Alec Guinness e Harrison Ford, entre muitos outros.

4 "Na minha percepção, Guerra nas Estrelas é um filme convencional de matinée, de mocinho e bandido, incrementado com efeitos visuais impressionantes."

5 “O western simplesmente trocou de roupas. A ópera a cavalo tornou-se a ópera espacial."

${ }^{6}$ Assim era chamada a região que ficava entre a cadeia dos Apalaches e o Rio Mississipi no fim do XVIII.

${ }^{7}$ Leatherstocking literalmente significa meias de couro, uma referência às vestimentas de couro usadas pelos indígenas e adotadas pelos pioneiros e caçadores.

${ }^{8}$ Para uma abordagem deste romance com relação à trajetória do pai de Cooper e da própria fundação da cidade de Cooperstown, ver Taylor, 1996.

${ }^{9}$ Os romances Waverley é a denominação dada aos romances históricos de Walter Scott publicados com a denominação "do autor de Waverley" ao longo de sua carreira. ${ }^{10}$ Assim como o pioneer era uma versão anglo-saxônica do caçador de peles de origem francesa, o cowboy era a versão dos EUA para o vaquero mexicano.

${ }^{11}$ Tratavam-se de publicações de qualidade editorial e gráfica muito baixas, muitas vezes não autorais, destinadas a um público pouco letrado. A expressão dime novel deve-se ao custo barato das mesmas, um décimo de dólar.

${ }^{12}$ Tratam-se de Theodore Roosevelt (1901), Ronald Reagan (1981-1989) e George Walker Bush (2001-2009). Suas imagens ligadas ao mito nacional, provavelmente tenha contribuído para o exercício de dois mandatos presidenciais exercidos pelos três. Sobre o primeiro, existe um texto já canônico de Dee Brown (BROWN, s/d). 


\section{Entre Cabanas e Diligências: Os Fronteiriços na Western Fiction...}

${ }^{13}$ Há uma versão em português (LEWIS, 2004, p. 22).

${ }^{14}$ The Outcasts of Pokerflat (Párias do Vício, no Brasil), de 1919, dirigida por John Ford e estrelada por Harry Carey.

15 Stagecoach (No Tempo das Diligências, no Brasil), de 1939, direção também de John Ford, estrelando Claire Trevor e John Wayne.

16 "Reverendos carregam revólveres na medida em que enfrentam assaltantes, ladrões de cavalos e prostitutas abnegadas."

17 "Ele era um pioneiro da literatura que ajudou a desenvolver uma fórmula, incluindo um conjunto de personagens, aos quais os escritores de western seguem desde então."

${ }^{18}$ Assim como Harte, Mark Twain viajou para o Oeste exercendo várias atividades, que descreveria em Roughing It (TWAIN, 1980). Esteve na Califórnia em 1866, quando tornou-se amigo de Harte, de quem seria sócio por algum tempo quando já estavam de volta ao Leste.

${ }^{19}$ Oakhurst aparece também no conto The Luck of Roaring Camp, publicado em 1968 (HARTE, 2001, p. 16-26).

20 “Experimentou-se um espasmo de reações virtuosas, tão desprovidas de regras e ingovernáveis quanto quaisquer dos atos que lhe deram origem"

${ }^{21}$ A tradução mais adequada seria "ladrão de calha". O minério de ouro era catado na água que escorria por calhas de madeira depois de canalizada dos cursos d'água. 22 "familiarmente conhecida como Duquesa"

23 “'Tommy, você é um bom moço, mas não sabe jogar sequer um centavo. Não tente de novo."

24 “'Piney pode ficar com a Sra. Oakhurst,' disse o Inocente, apontado para a Duchess, 'e eu posso me virar sozinho."”

25 "'Presumo que você esteja acostumada a coisas boas em Poker Flat, disse Piney. Duchess virou-se repentinamente para esconder que algo havia lhe corado as bochechas por trás de sua fachada profissional, e Mother Shipton pediu a Piney para não tagarelar."

26 "Ele não acordou os que estavam dormindo. O Inocente ressonava pacificamente, com um sorriso em seu rosto sardento bem-humorado; a virgem Piney dormia ao lado de suas irmãs mais frágeis, como se cuidada docemente por guardiões celestes."

27 ، 'Poker!', respondeu Oakhurst, de forma sentenciosa; 'quando um homem tem sorte - sorte de negro - ele não se cansa. A sorte vai embora primeiro. Sorte,' continuou o jogador, reflexivamente, 'é uma coisa muito estranha. Tudo o que você sabe com certeza é que ela vai mudar.' “

28 "E é descobrindo quando ela vai mudar que importa. Já tivemos muito má sorte desde que deixamos Poker Flat, vocês chegam e entram nela. Se vocês conseguirem segurar suas cartas juntos, vocês ficarão bem." 
29 “'Dêem-nas para a criança,' disse ela, apontando para Piney, que dormia. 'Você se matou de fome,' disse o jogador, 'É assim que eles chamam,' disse a mulher, de maneira queixosa, enquanto se deitava novamente, virando-se para a parede, e morreu silenciosamente."

30 ““'Até o canyon,' ele respondeu. Virou-se repentinamente e beijou Duchess, deixando seu rosto pálido em chamas e seus braços trêmulos rígidos com a surpresa. 31 “ 'Piney, você sabe rezar?' 'Não, querido,' disse Piney, de forma simples."

32 "Embaixo desta árvore jaz o corpo de John Oakhurst, que teve uma maré de má sorte no dia 23 de novembro, 1850, e entregou seus pontos no dia 7 de dezembro, 1850." 33 “[...] era ao mesmo tempo o procristo mais forte e mais fraco de Poker Flat" 34 "Das histórias de Harte brotaram inúmeras lendas e histórias inacreditáveis, que acabaram por se tornar conteúdo de westerns e seriados de televisão."

${ }^{35}$ Stage é a forma abreviada de stagecoach, literalmente um "coche por etapas"; uma tradução mais habitual é "diligência".

36 "Esse é um daqueles anos no Território em que sinais de fumaça Apache espiralavam dos picos rochosos de montanhas."

37 "Lá embaixo, no deserto a distância, ficavam as estações de transferência por que eles esperavam passar. No meio havia uma região esvaziada pelos saques rápidos dos homens de Gerônimo."

${ }^{38} \mathrm{O}$ conto não traz datação. Gerônimo foi um dos principais chefes guerreiros dos Apaches Chiricahuas, combatendo nos principais conflitos contra mexicanos e estadunidenses desde 1858. Suas últimas rebeliões ocorreram de 1877 a 1986, portanto este deve ser o marco temporal da narrativa. (BROWN, 2001; GERÔNIMO; BARRETT, 1986; REEDSTROM, 1990)

39 “[...] uma garota comumente conhecida no Território como Henriette veio silenciosamente do grupo. Ela era pequena e quieta, com um toque de palidez em suas bochechas e seus olhos escuros ergueram-se ao sinal da cortesia inesperada do homem loiro, demonstrando surpresa."

40 "Homens na multidão estavam rindo, mas o loiro virou-se, seus movimentos como o cortar rápido de uma faca, e sua atenção tomou conta daquele grupo até que os sorrisos cessaram. Ele era alto, magro e definitivamente marcado pelas armas penduradas para baixo em sua cintura."

${ }^{41}$ Grande parte dos comentadores do conto associam o papel de Henriette ao da prostituta Elisabeth - a "Boule de Suif”' (Bola de Sebo) - que, durante a guerra franco-prussiana, salvou a acompanhante que a desprezavam, entregando-se aos prazeres de um prussiano (MAUPASSANT, 2011).

${ }^{42}$ Impressiona a semelhança com a descrição da prostituta Dutchess feita por Harte:"familiarmente conbecida como..." (HARTE, 1997, p. 13).

43 "Ela falou de jeito direto, paciente, como se explicando algo que ele deveria saber sem perguntar. 'Eu vou para uma casa em Lordsburg."” 
44 "Johnny Strang mexeu na arma no seu colo. 'Para que Malpais Bill está indo com a gente?' 'Acho que eu não perguntaria para ele,' respondeu Happy Stuart.” 45 "seu sorriso de tropeiro e a ousadia de seu olhar eram tão audíveis quanto sua fala" 46 "O jogador falou com a garota, delicadamente: 'Talvez você ache meu assento mais confortável.' A garota disse 'Obrigada' e trocou de lugar."

47 "Mas alguma coisa emanava dele na direcção dela que era diferente da curiosidade predatória de outros homens; algo discretamente cavalheiresco, inesperadamente gentil."

48 "Havia uma sabedoria nela, um conhecimento dos medos de que os homens escondem por trás de seus gestos, as fomes profundas que os moviam tão selvagemente, e a solidão que os levavam a procurar mulheres do seu tipo."

49 "Olá, Bill. O que o trás por esses lados?"

50 "Melhor não ir até Lordsburg. Plummer e Shanley estão lá."

51 "Meus pais morreram - eu acho."

52 "Ela havia sobrevivido e havia pagado por sua sobrevivência, e olhava para ele agora de um jeito silencioso que não oferecia explicações ou desculpas pelo que havia passado."

${ }^{53}$ Ranch no oeste dos Estados Unidos e Rancho no norte mexicano são propriedades de criação de gado, de extensão variável.

54 "uma dívida a se coletar"

55 “"Todos no Território o conhecem. Certa vez você era apenas um rancheiro. Daí você tentou acabar com uma briga e depois havia outra maior ainda para acabar - e a dívida continuou crescendo e há mais homens esperando para matá-lo." 56 “'Eu estou a observando há dois dias.' Ele parou, procurando em sua mente a coisa certa a se dizer. Saiu bem rápido. 'Eu fiz de você uma mulher. O Tonto é um lugar bonito.

57 "Não. Eu sou conhecida em todo o Território. Mas eu vou lembrar que você pediu."

\section{Referências}

BOONE, Daniel; HAWKS, Francis L. Daniel Boone: His Own Story \& The Adventures of Daniel Boone, the Kentucky Rifleman. Bedford (Massachusetts): Applewood Books, 1996.

BORGES, Jorge Luis. La Poesía Gauchesca. In: Discusión. Buenos Aires: Delbolsillo, 2012, p. 13-41.

BROWN, Dee. Teddy, o Cavaleiro Destemido. In: O Faroeste. Rio de Janeiro: Record, s/d, p. 271-286. 


\section{Cesar Augusto Barcellos Guazzelli, Renata Dal Sasso Freitas}

BROWN, Dee. The Last of the Apache Chiefs. In: Bury my heart at Wounded Knee: na Indian history of the American West. New York: Henry Holt, 2001, p. 391-413.

COOPER, James Fenimore. Os Pioneiros. Sintra: Publicações Europa-América, s/d. . O último dos moicanos. Rio de Janeiro: W. M. Jackson Editores, 1947 (Grandes Romances Universais, vol. 6). . The Pioneers (or The Sources of the Susquehanna). New York: Penguin, 1964. . The Pathfinder (or The Inland Sea). New York: Penguin Books, 1980. . The Deerslayer (or The First Warpath). New York: Bantam Books, 1982. . The Prairie (A Tale). New York: Penguin Books, 1987. . The Last of the Mobicans (A Narrative of 1757). New York: Bantam Books,

1989.

CROCKETT, David. A Narrative of the Life of David Crockett of the State of Tennessee, Written by Himself. Lincoln: Nebraska University Press, 1987.

FREITAS, Renata Dal Sasso. Páginas do Novo Mundo: um estudo comparativo entre a ficção de José de Alencar e James Fenimore Cooper na formação dos Estados nacionais brasileiro e norte-americano no século XIX. Porto Alegre: UFRGS (Dissertação), 2008.

. Love of Country: os romances históricos de James Fenimore Cooper sobre a Guerra de Independência dos Estados Unidos (1821-1824). Rio de Janeiro: UFRJ (Tese), 2012. GIARDINELLI, Mempo. El género negro: orígenes y evolución de la literatura policial y su influencia en Latinoamérica. Buenos Aires: Capital Intelectual, 2013.

GERÔNIMO; BARRETT, S. M. Gerônimo, uma autobiografia. Porto Alegre: L \& PM Editores, 1986.

GUAZZELLI, Cesar Augusto Barcellos. Fronteiras americanas na primeira metade do século XIX: o triunfo das representações nos Estados Unidos da América. Anos 90. Porto Alegre: UFRGS, nº 18, dez. 2003, p.124-144.

.; FERREIRA, Letícia Schneider; MONTEIRO, Lucas Maximiliano; GONZAGA, Sandro. Tio Sam vai à guerra. Os conflitos bélicos dos Estados Unidos através do cinema. Porto Alegre: Letra \& Vida, 2010.

.; BECK, José O. José Orestes. 4 de julho: um western no espaço. In: GUAZZELLI, Cesar Augusto Barcellos; FERREIRA Letícia Schneider; MONTEIRO Lucas Maximiliano; GONZAGA, Sandro, 2010. p. 253-274.

HARTE, Bret. The Outcasts of Poker Flat. Gold Rush. Berkeley (CA): Heyday Books, 1997, p. 12-22. 
HARTE, Bret. The Outcasts of Poker Flat. The Luck of Roaring Camp and Other Writings. New York: Penguin Books, 2001, p. 27-37.

. Os proscritos de Poker Flat. In: LEWIS, Jon E. Os melhores contos de faroeste: uma antologia de histórias clássicas da fronteira americana. Rio de Janeiro: José Olympio, 2004, p. 22-32.

HAYCOX, Ernest. Stage to Lordsburg. In: JAKES, John. A century of great western stories: na anthology of western fiction. New York: Forge Books, 2000, p. 413-425.

HOBSBAWN, Erich. O caibói americano: um mito internacional? In: Tempos fraturados. São Paulo: Cia das Letras, 2013, p. 310-329.

JAKES, John. Introduction: What Happened to the Western? In. JAKES, John. (Ed.). A century of great western stories: na anthology of western fiction. New York: Forge Books, 2000. p. 11-17.

LEWIS, Jon E. Os melhores contos de faroeste: uma antologia de histórias clássicas da fronteira americana. Rio de Janeiro: José Olympio, 2004.

MARGOLIN, Reuben H. Introduction. In: HARTE, Bret. Gold Rush. Berkley (CA): Heyday books, 1997.

MAUPASSANT, Guy. Bola de Sebo. Artes e Ofícios, 2011.

NABUCO, Carolina. Retrato dos Estados Unidos à luz de sua Literatura. Rio de Janeiro: Nova Fronteira, 2000.

REEDSTROM, Ernest. Lisle. Apache Wars. New York: Barnes \& Nobles, 1990.

SCHARNHORST, Gary. Introduction. In: HARTE, Bret. The Luck of Roaring Camp and Other Writings. New York: Penguin Books, 2001.

TAYLOR, Alan. William Cooper's Town. New York: Vintage Books, 1996.

TWAIN, Mark. Roughing It. New York: Signet Classics, 2008.

VARGAS LLOSA, Mário. La Verdad de las Mentiras. Barcelona: Editora Alfaguara, 2002.

Escrito pelo organizador do dossiê. 